Nig. J. Biotech. Vol. 34 (2017) : 125-132

ISSN: 01891731

Available online at

http://www.ajol.info/index.php/njb/index

and www.biotechsocietynigeria.org

DOI: https://dx.doi.org/10.4314/njb.v34i1.16

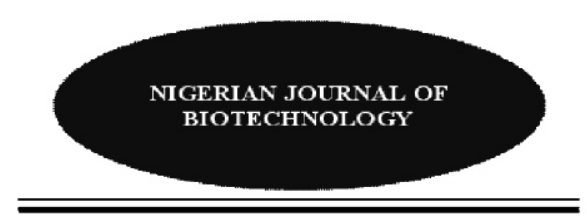

\title{
Effect of Physico-chemical Factors and Plankton Abundance in Selected Tropical Fish Earthen Ponds' Water
}

\author{
Chukwu, M. N. ${ }^{{ }^{*}}$ and Afolabi, E. S. ${ }^{2}$ \\ ${ }^{1}$ BiologyUnit, Department of Pure and Applied Sciences, Faculty of Science, National Open University of Nigeria Headquarters, \\ 91 Cadastral Zone, Nnamdi Azikiwe Express Way. Jabi-Abuja, Nigeria \\ ${ }^{2}$ Department of Aquaculture, Nigerian Institute of Marine Research and Oceanography, Victoria Island, Lagos, Nigeria \\ Copyright resides with the authors in terms of the Creative Commons License. 4.0. \\ See http://creativecommons.org/licenses/by/4.0/ \\ Condition of use: The user may copy, distribute, transmit and adapt the work, but must recognize the authors \\ and the Nigerian Journal of Biotechnology.
}

\begin{abstract}
The study investigated the plankton diversity and abundance of three selected on-farm research fish ponds in Nigerian Institute for Oceanography and Marine Research, Lagos. Samples were taken from three ponds using standard procedure and physico- chemical features of the water bodies were measured. Plankton of class (Bacillariophyceae, Chlorophyceae, Cyanophyceae and EuglenophyceaeI) and Zooplanktons of (Cladocera, Rotifera and Copepoda) family were found. There were varying results for the phytoplaktons and zooplaktons respectively during the study. The highest percentage composition for phytoplankton was recorded in Pond $1(94.11 \%)$, and the highest Shannon-Weaner diversity $(1.265 \%)$ in pond 2 . The highest percentage of zooplankton was recorded in pond $2(91.67 \%)$. Utilizing the parameter of Shannon index value, the abundance value for zooplaktons was not remarkable. Statistical association between parameters and abundance reflected that abundance was positively correlated with temperature, and negatively correlated with $\mathrm{pH}$ while the levels of dissolved oxygen (DO) were positively correlated. The low densities and plankton diversity in pond 3 was an indication of low pH and high transparency as a result of nutrient depletion.
\end{abstract}

Keywords: Abundance; physico-chemical factors; phytoplankton; zooplankton; fish ponds

Correspondence: mchukwu@noun.edu.ng and ade ife@yahoo.com

\section{Introduction}

The richness of planktons and its interaction with the environment as essential for fish production. Wetzel (1989) showed that fresh water production which influences the growth of fish, is also influenced by its physical, chemical, and biological contents. According to Sikoki and Veen, (2004), plankton productivity is a function of ecological, chemical and physical factors respectively. Wetzel (1989) further showed that fresh water production which influences the growth of fish is also influenced by its physical, chemical, and biological contents.

Abowei (2010) reported that the population density of plankton production and its distribution is a greatly influenced by physical, chemical and environmental factors. Furthermore, Santhosh and Singh (2007) established that the relationship between the physico-chemical parameters of water quality and plankton production in fish ponds is of great importance to fish culture. Reasonable fish production is greatly influenced by biological and physo-chemical qualities of water (Ugwumba and Ugwumba, 1993; Santhosh and Singh, 2007). Sharmin et. al. (2015) showed that phytoplankton composition and abundance were variable in freshwater fish ponds. Several studies on the physical and chemical parameters on some indigenous habitats had been undertaken (APHA, 1991; Boyd, 1998). 
Allen, (1991) found that in fish production, understanding the hydrological conditions and the planktons of given water were not only enough, as they also throw more light on the life cycle and population of any fish community. This study thus aimed at evaluating plankton taxonomic composition, biomass and community structure under different pond management to determine the effect and interdependence of physico-chemical parameters on their community structure.

\section{Materials and Methods}

Study Area

The study area was the Nigerian Institute for Oceanography and Marine Research (NIOMR) Lagos, Badore out station (Plate 1), located off Ado Badore road. The land lies between $06^{\circ} 30^{\prime}$ 47.8" $\mathrm{N} 06^{\circ} 30^{\prime} 24.01^{\prime \prime} \mathrm{N}$ and $03^{\circ} 36^{\prime} 00.13^{\prime \prime} \mathrm{E} 03^{\circ}$ $36^{\prime} 19.31^{\prime \prime} \mathrm{E}$ off the coast of Lagos, Nigeria with total land area of 29.455 hectares (Okoro, 2014). Three on-farm research fish ponds located within the same station, $50 \mathrm{~m}$ apart and $1.5 \mathrm{~km}$ off Lagos lagoon were used for the study. The source of water supply for the fish ponds was drilled borehole. Sampling ponds 1 and 3 were stocked with Oreochromis niloticus while pond 2 was stocked with Oreochromis niloticus and Clarias gariepinus.

\section{Sampling techniques}

Physico-chemical parameters and total plankton abundance were measured from the sample ponds. Sampling took place between September, 2017 and November, 2017. Samples were collected from the ponds between 09.00 a.m. and 10.00 a.m. once a week. The pH, salinity, dissolved oxygen, temperature and water transparency measurements were taken in-situ. Transparency and temperature were measured with Secchi disc of diameter $20 \mathrm{~cm}$ and mercury in glass thermometer respectively.
Digital electronic meter (JPB-607A) was used to measure the dissolved oxygen (DO). The $\mathrm{pH}$ was measured with electronic probe $(\mathrm{pH}-98108)$ and salinity with (RHW-25 Brix (ATC)).

\section{Phytoplankton sampling and analysis}

Samples for plankton analysis were collected using a cone shaped, silk bolting cloth $53 \mu \mathrm{m}$ plankton net with a $50 \mathrm{ml}$ concentration bottle. The $50 \mathrm{ml}$ concentrates were transferred to separately labeled $100 \mathrm{~mL}$ glass jars and fixed immediately with $5 \%$ formalin from four sampling points. The fixed samples were allowed to settle in the laboratory for 24 hours and the supernatant carefully discarded until concentration of about $40 \mathrm{ml}$ was obtained. Phytoplankton species were examined, identified and counted using Trinocular Olympus microscope equipped with digital scope photo ( $\times 9)$ and computer system window 2000 at $10 \times$ and $40 \times$ objectives using drop count method as described by (Santhosh and Singh, 2007).

\section{Statistical analysis}

One way analysis of variance was utilized in data analysis (ANOVA) at $5 \%$ level of significance. Density of the plankton species and their diversity were determined with Shannon-Weaver diversity index while Karl Pearson correlation coefficient was used to determine the correlation between the physico-chemical parameters.

Results and discussion

\section{Water quality parameters}

The physico-chemical parameters of the sampled ponds fell within the standard range except pond 3 with slight deviation from the trend where the $\mathrm{pH}$ of the pond water was slightly low. This may be harmful to non-acid tolerant phytoplankton, thus the low phytoplankton abundance in the pond (Fig. 1). Mean transparency values were similar to those documented by (Abowei, 2010) 


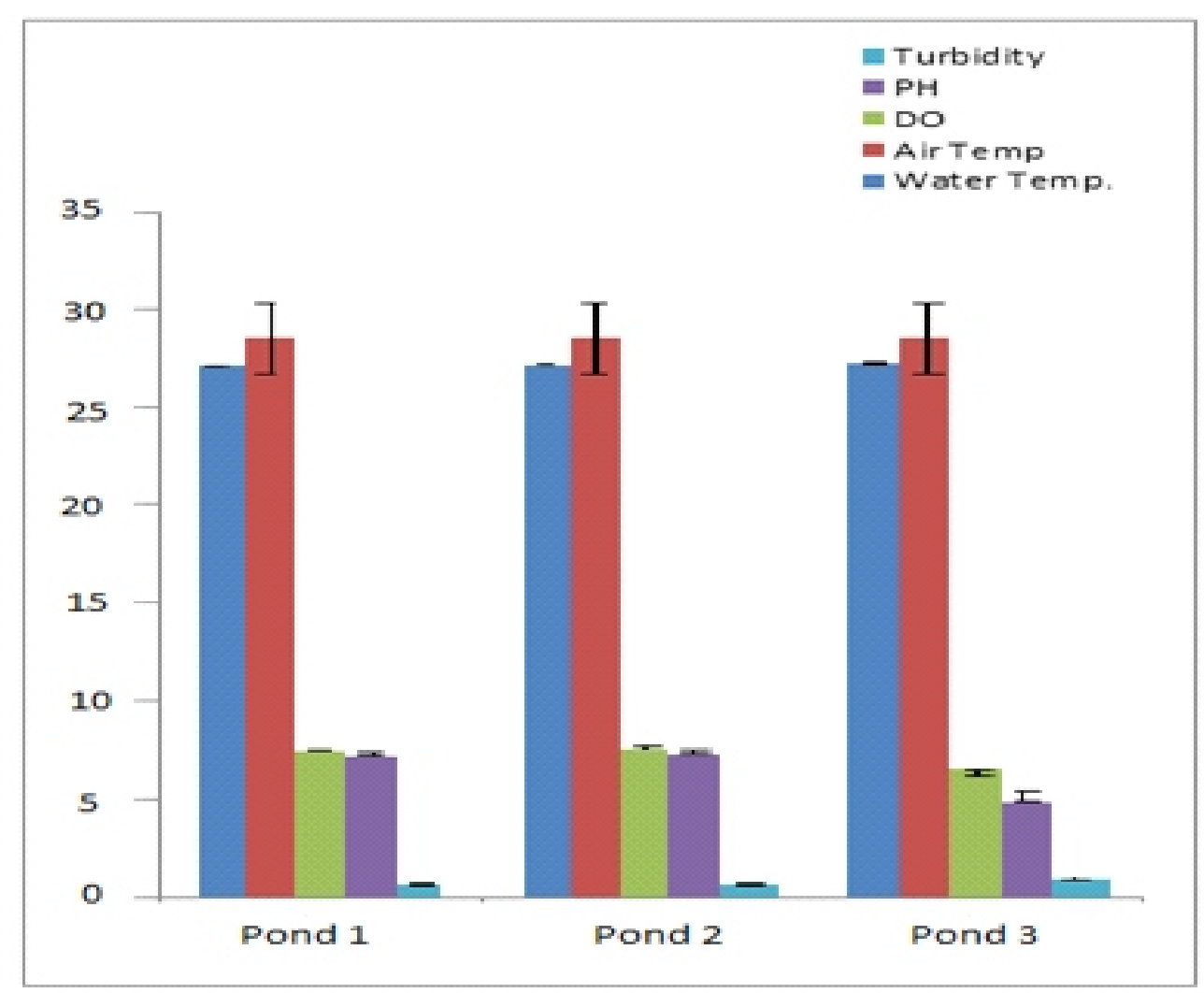

Figure 1 Physico-chemical parameters in the ponds.

Values shown $=$ mean \pm SEM

The high turbidity of Ponds 1 and 2 showed that the various nutrients in both ponds' waters were adequate. Same was concord by Abowei (2010). The water temperatures fall within acceptable range $\left(24^{\circ} \mathrm{C}\right.$ to $\left.34.0^{\circ} \mathrm{C}\right)$ for the tropics. The dissolved oxygen was within the optimum range; 5.0 to $15.0 \mathrm{mg} \mathrm{L}^{-1}$ (Fig.1) which facilitates plankton abundance and distribution. This is in agreement with the findings of (Ekubo and Abowei, 2011; Santhosh and Singh, 2007).

Distribution pattern, abundance and community structure of plankton

The phytoplankton community consisted of 17 genera belonging to four families; Chlorophyceae (6), Cyanophyceae (5), Bacillariophyceae (5) and Euglenophyceae (1). The Chlorophyceae was the most abundant, followed by Bacillariophyceae, Cyanophyceae and Euglenophyceae. The impact of massive phosphatase draining in a rich agricultural land and sun light probably contributed to the dominance and abundance of chlorophyceae and bacillariphyceae in a pond. This is in line with the findings of Udo (2007) and also Ogbeibu and Victor, (1995).

There is variation of the range of species in each pond (13-16). Pond 1 had the highest number of species (16) while the least number of species (13) was recorded from the pond 3 . The high phytoplankton abundance in pond 1 with light bloom could be attributed to the ponds' water management. Same was concord by Abowei (2010).

Twelve zooplankton species belonging to three families were recorded; Cladocera (4), Rotifera (6) and Copepoda (2) (Table: 1). Copepoda species were common to all the ponds. Species richness was highest in Pond 2 and least in pond 3 while richness index for zooplankton was low in all the ponds. Phytoplankton species were significantly higher than zooplankton species ( $P$ $>0.05$ ). 
Table 1 : Richness and frequency of occurrence of plankton species in the Ponds

\begin{tabular}{|c|c|c|c|c|c|c|}
\hline \multirow{2}{*}{ PARAMETERS } & MAJOR GROUPS & GENERA & POND1 & POND2 & POND3 & \multirow{2}{*}{$\begin{array}{l}\text { FREQUENCY } \\
\text { OF } \\
\text { OCQURRENCE }\end{array}$} \\
\hline & & & & & & \\
\hline \multirow{21}{*}{$\begin{array}{l}\text { Phytoplankton } \\
\text { Species }\end{array}$} & \multirow{5}{*}{ Bacillariophyceae } & Taballaria & $x \times x$ & $x x$ & $x$ & 1 \\
\hline & & Asterionella & $x x$ & $x x$ & A & 0.67 \\
\hline & & Cyclotella & $x x$ & $x x$ & $x x$ & 1 \\
\hline & & Surrirella & $x x$ & $x$ & $A$ & 0.67 \\
\hline & & Navicula & $x x x$ & $x x$ & $A$ & 0.67 \\
\hline & TOTAL & 5 & 5 & 5 & 2 & \\
\hline & \multirow[t]{5}{*}{ Cyanophyceae } & Microcysti & $x x$ & $x x$ & $x$ & 1 \\
\hline & & Gomphospaeria & $x$ & $x x$ & $A$ & 0.67 \\
\hline & & Anabaena & $x x x$ & $x x x$ & $x x$ & 1 \\
\hline & & Oscillatoria & $x x$ & $x x$ & A & 6.67 \\
\hline & & Aphanocapsa & $x$ & $A$ & $A$ & 0.33 \\
\hline & TOTAL & 5 & 5 & 4 & 2 & \\
\hline & \multirow[t]{6}{*}{ Chlorophyceae } & Ulothrix & $x x$ & $x x$ & A & 0.67 \\
\hline & & Oocystis & $x x x$ & $x x x$ & A & 0.67 \\
\hline & & Pediastrum & A & $x$ & $x x$ & 0.67 \\
\hline & & Scenedesmus & $x x x$ & $x x x$ & $x x$ & 1 \\
\hline & & Chlorella & $x x x$ & $x x x$ & $x$ & 1 \\
\hline & & Actinastrum & $x$ & A & A & 0.33 \\
\hline & TOTAL & 6 & 5 & 5 & 3 & \\
\hline & Euglenophyceae & Euglena & $x x$ & $x x$ & $A$ & 0.67 \\
\hline & TOTAL & 1 & 1 & 1 & 0 & \\
\hline \multirow{15}{*}{$\begin{array}{l}\text { Zooplankton } \\
\text { species }\end{array}$} & \multirow[t]{4}{*}{ Cladocera } & Daphnia & $x x x$ & $x x x$ & A & 0.67 \\
\hline & & Ceriodaphnia & $x x x$ & $x x$ & $x x$ & 1 \\
\hline & & Moina & $x x x$ & $x x x$ & A & 0.67 \\
\hline & & Diaphanosoma & $x x x$ & $x x x$ & $x$ & 1 \\
\hline & TOTAL & 4 & 4 & 4 & 2 & \\
\hline & \multirow[t]{2}{*}{ Copepoda } & Diaptomus & $x x x$ & $x x x$ & $x$ & 1 \\
\hline & & Cyclops & $x x x$ & $x x x$ & $x$ & 1 \\
\hline & TOTAL & 2 & 2 & 2 & 2 & \\
\hline & \multirow[t]{6}{*}{ Rotifa } & Brachionus & $x x x$ & $x x x$ & $x$ & 1 \\
\hline & & Keratella & $x x x$ & $x \times x$ & $A$ & 0.67 \\
\hline & & Flinia & A & $x$ & A & 0.33 \\
\hline & & Keratella & $x x x$ & a & $A$ & 0.33 \\
\hline & & Polyarthra & $x x x$ & $x x x$ & A & 0.67 \\
\hline & & Hexarthra & A & $x x$ & $x$ & 0.67 \\
\hline & TOTAL & 6 & 4 & 5 & 2 & \\
\hline
\end{tabular}

Plankton enumeration and relative abundance rankings:

$X=1-15 \mathrm{cells} / \mathrm{ml}^{-1}$ (sparsely abundant)

$x x=16-63$ cells $/ \mathrm{ml}^{-1}$ (fairly abundant)

$\mathrm{xxx}=64-255 \mathrm{cells} / \mathrm{ml}^{-1}$ (very abundant)

$x x x x=256-1024$ cells $/ \mathrm{ml}^{-1}$ (most abundant)

$a=$ absence of not encountered in entire enumeration.

$\mathrm{O}=$ rare species occurrence encountered in the entire enumeration. 
Ta ble2 : Percentage Distribution and Diversity of Planktors

\begin{tabular}{|c|c|c|c|c|c|}
\hline \multirow{10}{*}{$\begin{array}{l}\text { Parameters } \\
\text { Phytoplankto } \\
\text { n }\end{array}$} & \multirow{2}{*}{$\begin{array}{l}\text { Abundance } \\
\text { Percentage } \\
\text { distibution }\end{array}$} & $\begin{array}{l}\text { Species } \\
\text { Baallariphyceae }\end{array}$ & $\begin{array}{l}\mathbf{P 1} \\
100\end{array}$ & $\begin{array}{l}\mathbf{P 2} \\
100\end{array}$ & $\begin{array}{l}\text { P3 } \\
40\end{array}$ \\
\hline & & Cyanophycee & 100 & 80 & 40 \\
\hline & \multirow{2}{*}{$\begin{array}{l}\text { of species } \\
(\%)\end{array}$} & Chlorophyceese & 83.33 & 83.33 & 50 \\
\hline & & Euglenophyceee & 100 & 100 & 0 \\
\hline & \multirow{4}{*}{$\begin{array}{l}\text { Spatial } \\
\text { distribution of } \\
\text { species(\%) }\end{array}$} & Baillarichycee & 41.7 & 41.7 & 16.8 \\
\hline & & Cyanophyceee & 45.5 & 26.6 & 28.57 \\
\hline & & Chlorophyceed & 38.4 & 38.4 & 23.1 \\
\hline & & Euglenophyceee & 50 & 50 & 0 \\
\hline & \multicolumn{2}{|c|}{ Percentagecomposition(\%) } & 94.11 & 88.23 & 41.17 \\
\hline & \multicolumn{2}{|c|}{ Shamon Weaver dversity index(H) } & 1.263 & 1.265 & 1.078 \\
\hline \multirow[t]{8}{*}{ Zooplankton } & \multirow{3}{*}{$\begin{array}{l}\text { Percentage } \\
\text { distribution of } \\
\text { species }(\%)\end{array}$} & Cadocera & 100 & 100 & 50 \\
\hline & & Copepocda & 100 & 100 & 100 \\
\hline & & Rodifa & 66.67 & 83.33 & 33.33 \\
\hline & \multirow{3}{*}{$\begin{array}{l}\text { Spatial } \\
\text { distribution of } \\
\text { species(\%) }\end{array}$} & Cadocera & 40 & 40 & 20 \\
\hline & & Copepocta & 33.33 & 33.33 & 33.33 \\
\hline & & Rodifa & 36.36 & 45.46 & 18.18 \\
\hline & \multicolumn{2}{|c|}{ Percentage composition(\%) } & 83.33 & 91.6 & 50 \\
\hline & \multicolumn{2}{|c|}{ Shamon Weaver diversity index $(H)$} & 1.054 & 1.036 & 1.097 \\
\hline
\end{tabular}

The densities of phytoplankton ranged from 1.85 $\times 10^{3}$ cells $\mathrm{L}^{-3}$ to $25.70 \times 10^{3}$ cells $\mathrm{L}^{-3}$ in all the ponds. There were significant differences in the cell densities of the phytoplankton in the ponds ( $P<0.05$; Fig. 2). Phytoplankton abundance was in the order, pond $1>$ pond $2>$ pond 3 (Figure 1 ) probably due to reduction of light bloom in the specified order.

High Shannon Weaver species diversity index in ponds 1 and 2 was an indication of greater species diversity in the two ponds. The high abundance of phytoplankton and zooplankton in ponds 1 and 2 was probably due to the suitable ecological conditions of the ponds. The differences in plankton composition, distribution pattern, abundance and community structure between the ponds showed that plankton distribution and abundance are affected by season, physical and chemical parameters, water movement, soil and biological factors. This is in agreement with the findings of Davies et al (2009).

The densities of the zooplankton ranged from $6.70 \times 10^{3}$ cells $\mathrm{L}^{-1}$ to $80.10 \times 10^{3}$ cells $\mathrm{L}^{-1}$ in all the ponds (Table 2). Zooplankton abundance was in the other, pond $1>$ pond $2>$ pond 3 (Figure 3 ) probably due to reduced light quality in that order. 


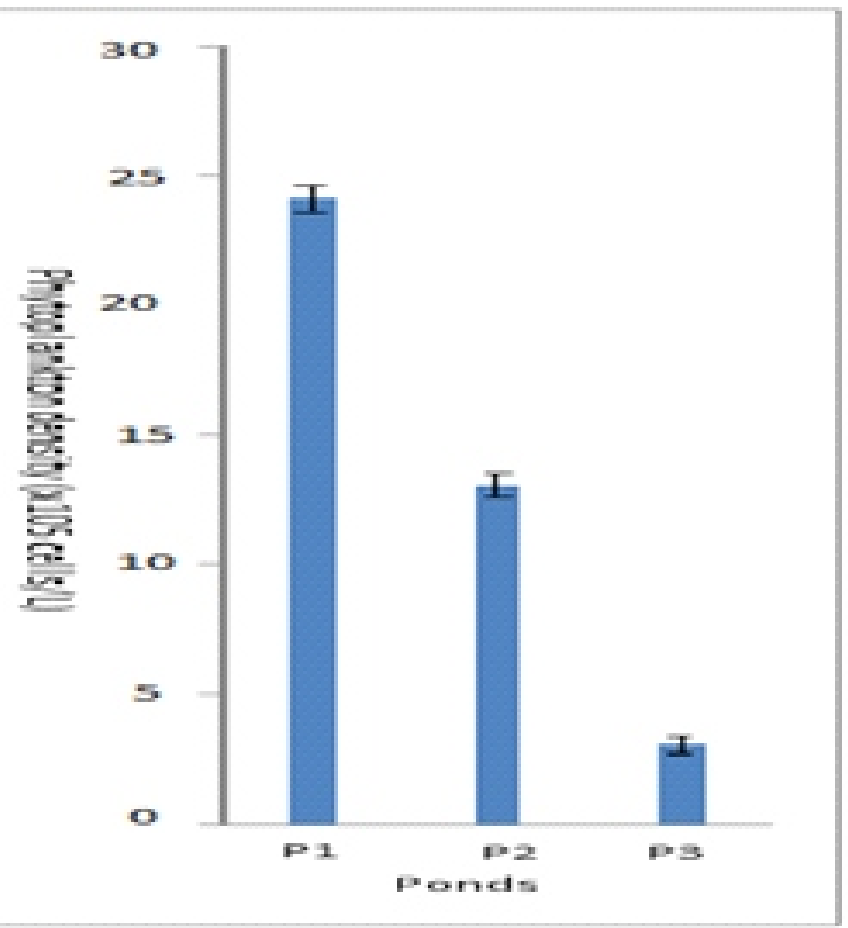

Figure 2: Cell densities of total phytoplankton in the ponds. Values shown $=$ mean \pm SEM

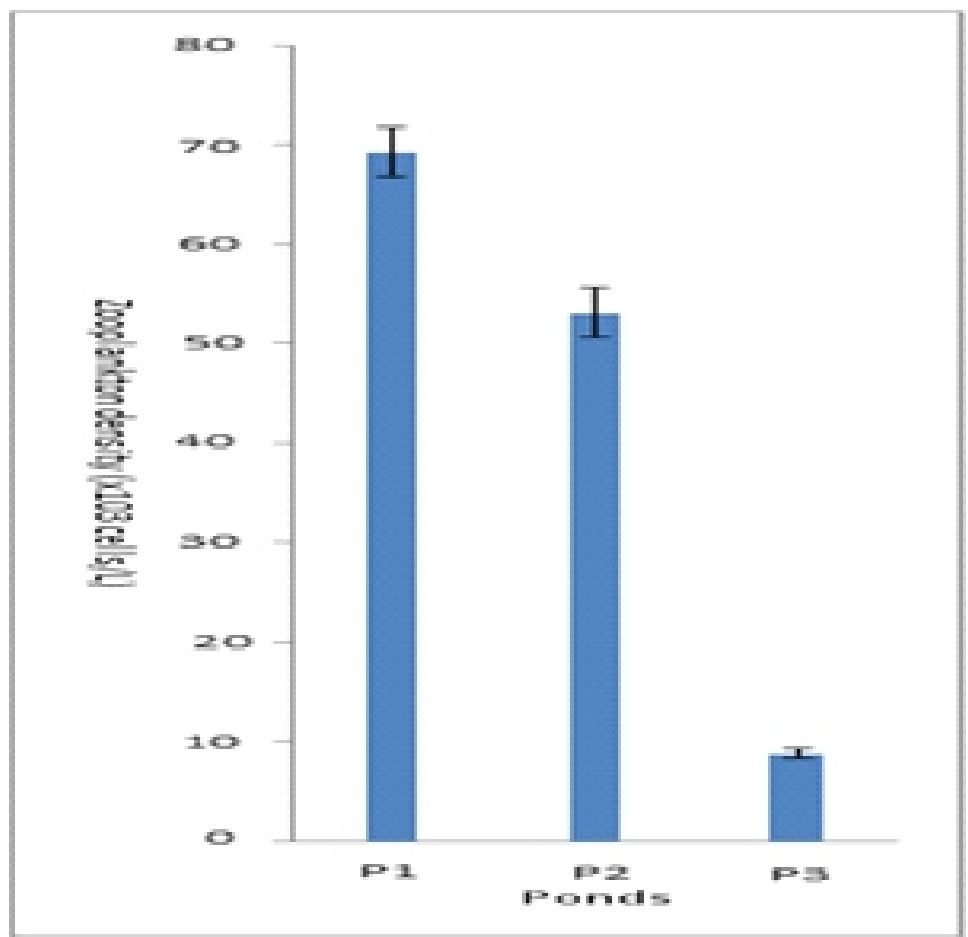

Figure 3 Cell densities of total zooplankton in the ponds. Values shown $=$ mean \pm SEM. 
Statistical association between parameters and abundance are shown in Table 3

Table 3: Correlation of Temperature, DO, pH and Plankton Abundance

\begin{tabular}{|c|c|c|c|c|c|c|c|c|c|c|c|c|}
\hline . & P1 & P2 & P3 & T1 & T2 & T3 & D01 & DO2 & DO3 & pH1 & pH2 & pH3 \\
\hline P1 & 1 & 0 & 0 & 0.528 & & & 0.870 & & & -0.726 & & \\
\hline $\mathbf{P 2}$ & 0 & 1 & 0 & & 0.647 & & & 0.690 & & & -1.081 & \\
\hline P3 & 0 & 0 & 1 & & & 0.942 & & & 0.0 .875 & & & -0.168 \\
\hline T1 & 0.528 & 0 & 0 & 1 & & & 0.716 & & & -0.1866 & & \\
\hline $\mathbf{T} 2$ & & 0.647 & & & 1 & & & 0.942 & & & -0.018 & \\
\hline T3 & & & 0.942 & & & 1 & & & 0.479 & & & -0.706 \\
\hline D01 & 0.870 & & & 0.716 & & & 1 & & & -0.692 & & \\
\hline DO2 & & 0.690 & & & 0.942 & & & 1 & & & -0.443 & \\
\hline DO3 & & & 0.0 .875 & & & 0.479 & & & 1 & & & -0.249 \\
\hline pH1 & -0.726 & & & -0.1866 & & & -0.702 & & & 1 & & \\
\hline pH2 & & -1.081 & & & -0.436 & & & -0.443 & & & 1 & \\
\hline pH3 & & & -0.168 & & & -0.706 & & & -0.249 & & & 1 \\
\hline
\end{tabular}

KEYS: Pond (P1, P2, P3), Temperature (T), Dissolved Oxygen (DO), pH.

Plankton abundance was positively correlated with temperature (Table 3 ) and with the levels of $\mathrm{DO}$, but negatively correlated with $\mathrm{pH}$; $(\mathrm{r}=$ $0.72619),(r=-1.081)$ and $(r=-0.1681)$ in ponds 1,2 and 3 respectively. Low DO concentration during the sampling periods was probably because the samples were collected early in the morning, when the level of Carbon (IV) oxide was high due to respiration. The negative correlation between plankton abundance and $\mathrm{pH}$ was an indication that the higher the $\mathrm{pH}$ of the ponds' water the lower the phytoplankton abundance. This is in line with the findings of Davies et. al. (2009). The variations in transparency agreed with the findings of (Ogbeibu and Victor, 1995) that the phytoplankton biomass increase with increase in transparency, frequently associated with dry season.

\section{Conclusion}

The presence and distribution of phytoplaktons and zooplaktons were influenced by the physical and chemical changes in the water ponds. Phytoplankton and zooplankton respond rapidly to any change in water bodies which may adversely affect the aquatic life leading a reduction in biotic diversity. The quantity and quality of planktons showed that the ponds' water had reached threshold levels. There is thus a need for some corrective measures to maintain water chemistry of the ponds and enhance sustainability of cultured organism (fish).

\section{References}

Abowei, J. F. N. (2010). Salinity, Dissolved Oxygen, $\mathrm{pH}$ and surface water temperature conditions in Nkoro River, Niger Delta, Nigeria, Advance Journal of Food Science and Technology, 2(1): 16 - 21.

Allen, G. (1991). Freshwater fishes of Australia. T.F.H. Publications, p. 176.

Apha, (1991). Standard Methods for the Examination of Water and Waste Water, Including Bottom Sediments and Sludge. Le ed., American Public Health Association, New York, USA, p. 1193. 
Boyd, C. E. (1998). Water quality in ponds for aquaculture. Research and Development, Series Number 43. International Centre for Aquaculture and Aquatic Environments. Alabama Agricultural Experimental Station, Auburn University, Alabama, p. 402.

Davies, O. A. Abowei, J. F. N. and Otene, B. B.(2009). Seasonal abundance and distribution of plankton of Minichinda stream, Niger Delta, Nigeria. America of Journal Science Research 2 (2): $20-30$.

Ekubo, A. A. and Abowei, J. F. N. (2011). Review of some water quality management principles in culture fisheries, Research Journal of Applied Sciences, Engineering and Technology, 3(2): 1342 - 1357.

Ogbeibu, A. E. and Victor, R. (1995). Hydrological studies of water bodies in the okomu forest reserves (sanctuary) in Southern Nigeria, physico-chemical hydrology, Tropical Freshwater Biology, 4: 83 - 100.

Okoro, C. B. (2014). Study on optimum protein requirements of fingerlings of Megalops atlanticus under Different culture system. Ph.D. Thesis, Department of Fisheries Management,
Submitted for Michael Okpara University, p. 154.

Santhosh, B. and Singh, N. P. (2007). Guidelines for water quality management for fish culture in Tripura, ICAR Research Complex for NEH Region, Tripura Center, Publication no. 29

Sharmin, A., Mofizur, R. and Masuma, A. (2015). Composition and abundance of phytoplankton population in fish ponds of Noakhali District, Bangladesh American-Eurasian J. Agric. \&Environ. Sci., 15 (11): 2143 - 2148.

Sikoki, F. D. and Veen, J. V. (2004), Aspects of Water Quality and the Potential for Fish Production of Shiroro Reservoir Nigeria, Living System Sustainable development, 2, p. 7.

Udo, P. J. (2007). Techniques in Fish Farming, Practice and Management. Wusen Publishers, Calabar, p. 100

Ugwumba, A. O. and Ugwumba, A. A. (1993). A study of the physico-chemical hydrology and Plankton of Awba Lake in Ibadan, Nigeria. Fish Acadbiz. Comm.1 (1-4): 20 - 39.

Wetzel, G. (1989). Limnology, 2nd edition Saunders Co., Philadelphia, and PMCid: PMC534348V. 